\title{
The Effect of Using e-Learning for Enhancing Active Learning of Pre-service Teachers
}

\author{
Intira Robroo
}

\begin{abstract}
The purposes of this study were to compare the learning achievement of students with e-learning to enhance active learning for pre-service teachers and to study students' attitudes towards e-learning in active learning activities. The sample group used in the experiment was 31 people from cluster random sampling and drawing to determine the experimental group. The results indicated that there was significant difference at the level of .01 between the learning achievements of before and after learning. And students have the attitude towards the electronic lessons to enhance active learning for pre-service teachers at the highest level. When we considered each aspect found that learning attitude with e-learning is the highest level, followed by pursuing knowledge and the prudence in learning respectively. Therefore, concluded that this e-learning for enhancing active learning could be used for increased the leaners' achievements.
\end{abstract}

Index Terms-Active learning, e-learning, learning attitudes, pre-service teachers learning.

\section{INTRODUCTION}

Digital revolution for transforming into industry 4.0 has an impact on Thailand's transformation into Thailand 4.0. Thailand's educational administration requires setting objectives of human resource management, planning manpower development and preparing manpower after graduation in every levels. The adjustment of learning method is required to develop potential and capabilities of human resource, leading to skills, knowledge, competency that can be well-prepared to handle with change and borderless free-trade competition. Educational administration needs learning management and learner evaluation that reflects potential and competency of learners [1]. Instruction design to support lifelong learning and to be congruent with teacher profession and living requires learners to develop skills in self-knowledge acquisition, leading to lifelong learning by employing a wide variety of educational media that is suitable with lifestyle of learners these days and present technology. The combination of digital media and learning methods in enhancing learning process of learners by using information technology enables learners to quickly access to information, understand and efficiently review knowledge from several sources on the basis of reliable information. Using e-learning in instruction management helps design more

Manuscript received May 16, 2019; revised August 2, 2019.

Intira Robroo is with the Faculty of Education of Suan Sunandha, Rajabhat University, Thailand (e-mail: intira.ro@ssru.ac.th).
Efficient instruction management, despite of using e-learning in traditional face to face classroom. E-learning can help learners pay attention to learn required courses and selective courses [2]. Instruction management should provide opportunities to allow learners to participate in their own learning process and to cooperate in constructing new body of knowledge, which is active learning method, including basic elements, talking and listening, writing, reading, reflecting, and learning strategies which are small groups, cooperative work, case studies, simulation, discussion, problem solving, journal writing, and teaching resources by using homework assignments, outside speakers, teaching technology, prepared educational material and commercial and educational television [3]. Using e-learning is essential in current situation because information technology and telecommunications progress quickly and has high potential to enable learners to access to knowledge sources conveniently and speedily. e-learning used to enhance learning process is important and can respond learners that have different learning methods. Current instruction management should develop leaning methods to be corresponding with social progress and technological environment in the aspect of social communications that has changed very rapidly.

Therefore, learners will benefit from learning environment provided to access to learners widely and learners are stimulated to access to study courses every time everywhere by using wireless internet technology. Researchers are interested in creating e-learning for enhancing active learning of pre-service teachers that is congruent with technological advancement in the context of knowledge society, thus supporting highest efficient learning result for learners.

\section{OBJECTIVES OF THE RESEARCH}

1) To compare learning achievement result of learners who learn with e-learning for enhancing active learning of pre-service teachers.

2) To study attitude of learners on e-learning for enhancing active learning of pre-service teachers.

\section{RESEARCH HYPOTHESIS}

1) Learner's achievement result after learning with e-learning for enhancing active learning of pre-service teachers is higher than result before learning with e-learning.

2) Learner's attitude of both positive and negative side after learning with e-learning for enhancing active learning of pre-service teachers is in good level. 


\section{RESEARCH METHOD}

The experiment on e-learning for enhancing active learning of pre-service teachers will be carried out in the form of experimental design which is the one-group pretest-posttest design. The research methods are as follow:

1) To study the documents and researches which are related to active Learning, e-learning and attitude of students.

2) To determine the population and Random the sample group.

3) To study related theories and researches to create research equipment's.

4) To design the experiment and conduct the experiment with the sample group.

5) To compile data, analyze data and discuss the results.

\section{SCOPE OF THE RESEARCH}

\section{A. Scope of the Content}

Creating e-learning for Enhancing Active Learning of Pre-service Teachers uses the content in EDP2103 Educational Quality Assurance, Bachelor of Education Program, Suansunandha Rajabhat University, which consists of the principles and concepts of educational quality assurance, educational quality management, educational quality assurance system, educational quality assurance process, continuous knowledge and quality development activity, internal quality assurance system, and external quality assurance system.

\section{B. Population and Sample}

Population and sample used in this research is 470 students who studied first semester of third year for Bachelor of Education Program, Suansunandha Rajabhat University, Dusit, Bangkok. They are selected from 7 departments and are divided into 14 study groups. The researcher used Cluster Random Sampling and obtained 1 department and 2 study groups and then drew to set up group for test sampling which was 31 students in English program who used e-learning for enhancing active learning of pre-service teachers.

\section{Variables}

The independent variable was using e-learning for enhancing active learning of pre-service teachers that researcher develops.

The dependent variable was achievement result of learners who learned with e-learning for enhancing active learning of pre-service teachers

Learning attitudes of learners in e-learning for enhancing active learning of pre-service teachers

Research Instruments

1) Achievement test for educational quality assurance

2) Attitude test of learners in e-learning for enhancing active learning of pre-service teacher

\section{LITERATURE REVIEW}

\section{A. Active Learning}

Active learning management is defined as learning management that allow learners to participate in self-learning process by speaking, listening, writing, thinking for understanding knowledge content and transferring to others and ready to listen to other ideas, leading to cooperation of new body of knowledge. Meyers \& Jones (1993: 6) said that active learning management is defined as learning management that allows learners to speak, listen, write, and think. Concepts and knowledge received is the significant main component of active learning. Petty (2004: 1) said that active learning management is defined as learning management that allows learners to interact each other and instructors will enhance learners to learn more than knowledge received from lecture only. Components of active learning. Meyers \& Jones [3] described that the components of active learning consisting of 3 related factors which are basic elements, learning strategies, and teaching resources. Basic elements were comprised of talking and listening, writing, reading, reflecting. Learning strategies was comprised of small groups, cooperative work, case studies, simulation, discussion problem solving, journal writing. Teaching resources was comprised of providing homework assignments, outside speakers, teaching technology, prepared educational material, and commercial and educational television. Munoz, et al. [4] studied active learning in first-year engineering courses at Universidad Católica de la Santísima Concepción, Chile and found that active learning which used a wide variety of learning activities such as project-based learning, Case Studies learning can help escalate learner understanding and stimulate motivation of learners to learn in Engineering courses and help realize working as a team and listen comments from instructors and colleagues. In summary, e-learning for enhancing active learning for pre-service teachers that researcher developed can be brought to develop learners to have better learning achievement result and can be used with learners in every level. From the research of Thaman, Richa, et al. [5], promoting active learning in respiratory physiology positive student perception and improved outcomes, he found that learning achievement result of medical students about physiology of respiratory system in 2 groups of active and traditional learning was significantly different in statistical way ( $\mathrm{p}<0.05$ ). According to the survey about active learning, researcher found that active learning helped medical students understand content better $(94.1 \%)$ and then pay more attention $(89.4 \%)$, have more interaction with friends $(83.6 \%)$, have good linkage to clinical content $(80.5 \%)$. In summary, active learning enables learners to have more attention, understanding, and interaction, then leading to participation in learning process. A wide variety of learning process management helps learners and instructors have higher enthusiasm in learning. Active learning can be used in learning management in every disciplines. In addition, developing learners to be desired characteristics can be also used active learning.

\section{B. E-Learning}

E-learning is learning management that focuses on transferring knowledge to target group conveniently and quickly enough as desired by using several electronics instrument such as computers, cellular phones, tablets, 
internet, intranet, extranet, television signals, or satellite signals. in addition, e-learning provides knowledge in the format of computer-assisted instruction, web-based instruction, online learning, and distance learning via satellite, etc. Silverman et al. [6] classified e-learning into 3 formats. first format is fully online environment which learners do projects and communications in virtual delivery system with synchronous and asynchronous communications. The design will take into account that knowledge result that will not equal to traditional classroom. second format is hybrid course environment which combines e-learning and traditional learning as a learning method. Learners can set the most suitable content to present through online system whereas learning activities and projects are provided in traditional classroom. Third format is enhanced course environment which traditional classroom will be used but instructors will create enhanced course environment. learners can study further from online system. e-learning is designed by using technology-based learning with setting goals, defining strategies, choosing appropriate technologies, and evaluation. furthermore, behaviorism and constructivism are also adapted to use in designing e-learning, leading to appropriate learning quality for learners, timing, and environment such as internet, intranet, extranet, satellite broadcast, audio/video recorders, interactive $\mathrm{tv}$, video on demand, cd-rom/dvd, web-based learning, and online social network. Efficient and successful E-learning depends on learning environment management in several aspects such as interaction, discussion, learning content, learner-centered model, and learners' attitude. Using e-learning enhances learner-centered model and consider individual differences. Learners have freedom in self-learning, helping learners to practice responsibility for learning and enhance self-directed learning. However, E-learning has several advantages but still has limitations such as Face to Face and Space for social interaction, resulting in relationship, friendship and then reliability in society. These are important factors in cooperation of work society because learners who learn in universities have objectives in doing their profession in society. Therefore, the practice of coexistence in society is still important. In addition, the limitation in the aspect of Time that is not same may be obstacle for mutual learning. These limitations of E-learning may be corrected by mixed learning design using traditional classroom together with e-learning. The advantages of both e-learning and traditional classroom are combined systematically to enable learners attain learning objectives.

\section{Attitude}

Attitude means readiness condition or emotional feeling of a person has for something and expresses it in one way or another which resulted from a person' s response to situation involvement based on learning, experiences, and belief level. When attitude happens, it will last long time but it can be changed. Shaw \& Wright [7] explained that attitude happens when a person evaluates result from stimulants and transform into internal feeling that causes motivation in express behaviors, in the aspect of quality and intensity as well as negative and positive ways. From that wordings, it can be summarized that attitude will occur when a person receives learning experiences and influences of environment, then that person can be developed and changed when situation or condition changes.

\section{DATA COLLECTION}

\section{A. Attitude}

The experiment of using e-learning for enhancing active learning.

The experiment of using e-learning to enhance active learning was conducted in real classroom with 31 students of Bachelor of Education Program, Suansunandha Rajabhat University, who registered studying in the course of EDP2103 Educational Quality Assurance in the first semester of 2018. The researcher uses Quasi Experimental Research by the method of one-group pretest-posttest design.

\begin{tabular}{c|c|c}
\hline \hline Pretest & Treatment & Posttest \\
\hline$T_{1}$ & $X$ & $T_{2}$ \\
\hline \hline$X:$ treatment \\
$T_{1}$ : pretest \\
$T_{2}:$ posttest
\end{tabular}

Pretest was used for knowledge test of Educational Quality Assurance course. The experiment of using e-learning to enhance active learning had been used in the first semester of 2018 for 8 weeks. The learners had been taught with 6 e-learning lessons for enhancing active learning through internet network for 6 weeks and then had practiced doing a piece of work for 2 weeks. They were given a chance to review e-learning to enhance active learning independently. Posttest was used to evaluate achievement result of Educational Quality Assurance course. After the experiment, researcher provided learners to take the attitude test on e-learning for enhancing active learning of pre-service teachers.

\section{STATISTICAL USE}

The researcher analyzed mean and standard deviation of learning achievement result for both pretest and posttest of students who learned with e-learning for enhancing active learning of pre-service teachers. Then researchers compared these statistical values of pretest to posttest by Paired Sample t-Test at the reliability level of $95 \%$ and denied main assumption (h0) when p.value was lower or equaled 0.05 as Table I.

\section{A. Analysis Result for Achievement Result Comparison}

Analysis result for achievement result comparison of pretest and posttest of learning with e-learning for enhancing active learning of pre-service teachers was shown in the following table.

TABLE I: ANALYSIS RESULT FOR LEARNING ACHIEVEMENT SCORE COMPARISON

\begin{tabular}{lcccccc}
\hline \hline \multirow{2}{*}{ Sampling Group } & \multicolumn{9}{c}{ Pretest } & \multicolumn{2}{c}{ Posttest } & \multicolumn{2}{c}{ Difference } \\
\cline { 2 - 7 } & $\bar{x}$ & $S D$ & $\bar{x}$ & $S D$ & $\bar{x}$ & $S D$ \\
\hline $\begin{array}{l}\text { Achievement } \\
\text { Score }\end{array}$ & 9.94 & 2.29 & 55.71 & 1.74 & 45.77 & -0.56 \\
\hline \hline
\end{tabular}


Table I indicated that the difference of mean of Achievement Score of sampling group was higher $(\bar{x}=$ $45.77, S D=-0.56)$. When comparing pretest to posttest by using t-Test Dependent at the reliability level of $99 \%$, the result was shown in the following table.

TABLE II: THE COMPARISON RESUlT OF PRETEST AND POSTTEST DERIVED FROM LEARNERS WHO STUDIED THROUGH E-LEARNING FOR ENHANCING ACTIVE LEARNING OF PRE-SERVICE TEACHERS

\begin{tabular}{cccccc}
\hline \hline Experiment & $\bar{x}$ & $S D$ & $t$ & $d f$ & p.value \\
\hline Pre test & 9.94 & 2.294 & -90.98 & \multirow{2}{*}{30} & \multirow{2}{*}{$0.000^{*}$} \\
Posttest & 55.71 & 1.736 & & &
\end{tabular}

*statistical significance level at .01

Table II Mean of achievement result for pretest and posttest of learners who learned with learning with e-learning for enhancing active learning of pre-service teachers indicated p.value of 0.000 which was lower than .01 (denied main assumption $-\mathrm{H}_{0}$ ). This can be explained that posttest achievement result of learners who learned with e-learning for enhancing active learning of pre-service teachers was higher than pretest achievement result in statistically significant level of 0.01 .

\section{B. Attitude Analysis Result}

According to attitude analysis result of learners who learned with e-learning for enhancing active learning of pre-service teachers, researchers provides 2 aspects of learners' attitude about e-learning for enhancing active learning of pre-service teachers which are positive and negative aspects as following.

TABLE III: THE COMPARISON RESULT OF PRETEST AND POSTTEST DERIVED FROM LEARNERS WHO STUDIED THROUGH E-LEARNING FOR ENHANCING ACTIVE LEARNING OF PRE-SERVICE TEACHERS

\begin{tabular}{|c|c|c|c|c|}
\hline \multicolumn{2}{|r|}{ Learning Attitude } & $\bar{x}$ & $S D$ & Result \\
\hline \multicolumn{5}{|c|}{ Curiosity } \\
\hline 1. & $\begin{array}{l}\text { Continual knowledge searching in } \\
\text { new situations and problems }\end{array}$ & 4.48 & 0.63 & Highest \\
\hline 2. & $\begin{array}{l}\text { Continual participation about } \\
\text { Educational Quality Assurance }\end{array}$ & 4.06 & 0.77 & High \\
\hline 3. & $\begin{array}{l}\text { Continual following news about } \\
\text { Educational Quality Assurance }\end{array}$ & 4.81 & 0.48 & Highest \\
\hline 4. & $\begin{array}{l}\text { Needs for knowledge of } \\
\text { Educational Quality Assurance in } \\
\text { developing teacher profession }\end{array}$ & 4.87 & 0.34 & Highest \\
\hline \multicolumn{2}{|c|}{ Overall attitude in the curiosity aspect } & 4.56 & 0.55 & Highest \\
\hline \multicolumn{5}{|c|}{ E-learning } \\
\hline 8. & $\begin{array}{l}\text { E-learning enabling more } \\
\text { self-additional study }\end{array}$ & 4.58 & 0.76 & Highest \\
\hline 9. & $\begin{array}{l}\text { Happiness in studying with } \\
\text { electronics media }\end{array}$ & 4.74 & 0.68 & Highest \\
\hline \multicolumn{2}{|c|}{$\begin{array}{l}\text { Overall attitude in the Electronics Media } \\
\text { aspect }\end{array}$} & 4.66 & 0.72 & Highest \\
\hline \multicolumn{5}{|c|}{ Carefulness } \\
\hline 10. & $\begin{array}{l}\text { Reason Analysis every time } \\
\text { when assigned }\end{array}$ & 4.26 & 0.51 & Highest \\
\hline 11. & $\begin{array}{l}\text { Systematical planning for } \\
\text { assigned work }\end{array}$ & 4.32 & 0.48 & Highest \\
\hline 12 . & $\begin{array}{l}\text { Answer searching from reliable } \\
\text { sources }\end{array}$ & 4.45 & 0.68 & Highest \\
\hline 13. & $\begin{array}{l}\text { Information source investigation } \\
\text { before using as reference }\end{array}$ & 4.10 & 0.83 & High \\
\hline 14. & $\begin{array}{l}\text { Investigation of the mistakes in } \\
\text { work process }\end{array}$ & 4.19 & 0.87 & High \\
\hline 15 . & $\begin{array}{l}\text { Re-investigation after finishing } \\
\text { work }\end{array}$ & 4.55 & 0.72 & Highest \\
\hline \multicolumn{2}{|c|}{ Overall attitude in the carefulness aspect } & 4.31 & 0.68 & Highest \\
\hline \multicolumn{2}{|c|}{ Overall Learning attitude } & 4.51 & 0.65 & Highest \\
\hline
\end{tabular}

Table III indicated that positive learners' attitude about e-learning for enhancing active learning of pre-service teachers is in the highest level $(\bar{x}=4.51, S D=0.65)$. Positive learners' attitude about e-learning is in the highest level in every aspects which are Attitude in the e-learning aspect $(\bar{x}=4.66, S D=0.72)$, Attitude in the E-learning aspect $(\bar{x}=4.56, S D=0.55)$ and Attitude in the carefulness aspect ( $\bar{x}=4.31, S D=0.68$ ), respectively. Each item in the aspect has differences in mean as following. Overall attitude in the E-learning aspect is in the highest level ( $\bar{x}=4.66, S D$ $=0.72$ ). When considering each item in this aspect, we found that Happiness in studying with E-learning in the highest level ( $\bar{x}=4.74, S D=0.68$ ), followed by E-learning enabling more self-additional study ( $\bar{x}=4.58, S D=0.76$ ). Overall attitude in the Curiosity aspect is in the highest level ( $\bar{x}$ $=4.56, S D=0.55)$. When considering each item in this aspect, we found that Needs for knowledge of Educational Quality Assurance in developing teacher profession is in the highest level ( $\bar{x}=4.87, S D=0.34$ ), followed by Continual following news about Educational Quality Assurance ( $\bar{x}=4.81, S D=$ $0.48)$, Continual knowledge searching in new situations and problems ( $\bar{x}=4.48, S D=0.63$ ), respectively, and Continual participation about Educational Quality Assurance is in high level $(\bar{x}=4.81, S D=0.48)$. Overall attitude in the Carefulness aspect is in the highest level ( $\bar{x}=4.31, S D=0.68)$. When considering each item in this aspect, we found that Re-investigation after finishing work is in the highest level ( $\bar{x}=4.55, S D=0.68)$, followed by Answer searching from reliable sources ( $\bar{x}=4.45, S D=0.68)$, Systematical planning for assigned work ( $\bar{x}=4.32, S D=0.48)$, and reason analysis every time when assigned ( $=4.26, S D=0.51$ ), respectively, and Investigation of the mistakes in work process and Information source investigation before using as reference are in high level $(\bar{x}=4.19, S D=0.87 ; \bar{x}=4.10, S D=0.83)$, respectively.

Negative learners' attitude about e-learning for enhancing active learning of pre-service teachers is shown in Table IV as following.

TABLE IV: THE NEGATIVE LEARNERS’ ATTITUdE ABOUT E-LEARNING FOR ENHANCING ACTIVE LEARNING OF PRE-SERVICE TEACHERS

\begin{tabular}{|c|c|c|c|c|}
\hline & Learning Attitude & $\bar{x}$ & $S D$ & Result \\
\hline 1 & $\begin{array}{l}\text { Learners feel bored } \\
\text { when studying about } \\
\text { quality assurance }\end{array}$ & 2.90 & 0.75 & Moderate \\
\hline 2. & $\begin{array}{l}\text { Learners feel nervous } \\
\text { when studying with } \\
\text { electronics media }\end{array}$ & 2.23 & 0.76 & Low \\
\hline \multirow[t]{2}{*}{3.} & $\begin{array}{l}\text { Studying through } \\
\text { electronics media cannot } \\
\text { cause better educational } \\
\text { result }\end{array}$ & 2.16 & 0.73 & Low \\
\hline & $\begin{array}{r}\text { Overall negative learning } \\
\text { attitude }\end{array}$ & 2.55 & 0.75 & Low \\
\hline
\end{tabular}

Table IV indicated that overall negative learners' attitude on e-learning for enhancing active learning of pre-service teachers was in the low level $(\bar{x}=2.55, S D=$ 
0.75). When considering each item in overall negative learners' attitude. We found that Studying through electronics media cannot cause better educational result was in the lowest level ( $\bar{x}=2.16, S D=0.73$ ), followed by learners feel nervous when studying with e-learning $(\bar{x}$ $=2.23, S D=0.76)$, Learners feel bored when studying about quality assurance ( $\bar{x}=4.31, S D=0.68)$, respectively.

\section{CONCLUSION}

According to achievement result of learners who had studied with e-learning for enhancing active learning of pre-service teachers for 8 weeks, a difference between pretest and posttest increased and when we statistically analyzed, we found that posttest result is higher than pretest result significantly at the level of 0.01 . According to the analysis of learners' attitude on e-learning for enhancing active learning of pre-service teachers, overall positive learners' attitude about e-learning for enhancing active learning was in the highest level starting from the aspect of E-learning, Curiosity and Carefulness, respectively. When considering each item of E-learning aspect, we found different means, Happiness in studying with electronics media was in the highest level, followed by E-learning enabling more self-additional study. When considering each item of Curiosity aspect, we found that Needs for knowledge of Educational Quality Assurance in developing teacher profession was in the highest level, followed by Continual following news about Educational Quality Assurance which was in the highest level, and Continual knowledge searching in new situations and problems which was in the highest level, respectively. Continual participation about Educational Quality Assurance was in the high level. When considering each item of Carefulness aspect, we found that Re-investigation after finishing work was in the highest level, followed by Answer searching from reliable sources, systematical planning for assigned work, and reason analysis every time when assigned whereas Investigation of the mistakes in work process and Information source investigation before using as reference were in the high level. Overall negative learners' attitude about e-learning for enhancing active learning was in the low level' When considering each item, we found that Studying through e-learning cannot cause better educational result was in the low level, which had the lowest mean, followed by Learners feel nervous when studying with electronics media and Learners feel bored when studying about quality assurance.

\section{Discussion}

From this research, we found interesting point of achievement and learning attitude that should be brought to discussion based on logical concept as following;

The result of using e-learning for enhancing active learning of pre-service teachers consists of active learning activities, hybrid course environment which is learning that mixes traditional classroom with online learning [6]. This learning type focuses on learner-centered according to
Brown et al. [8] and has resources that support efficient e-learning and is suitable for knowledge and capabilities of learners and is also congruent with learning objectives.

When considering learning achievement result of sampling group for both pretest and posttest who learned through e-learning for enhancing active learning of pre-service teachers, we found that learning achievement result for pretest and posttest was significantly different at the level of .01. This indicates that e-learning for enhancing active learning researcher developed helped achievement result higher which was congruent with research work of Jirapha Autthaporn [9] in the topic of development of an active online instructional model to enhance learning behaviors of undergraduate students. The research result found that learning behaviors of sampling group was significantly higher in each week at the statistical level of .05 and was congruent with the research work of Munoz, and Martinez [4] about active learning in first-year engineering courses at Universidad Católica de la Santísima Concepción, Chile.

The research result found that active learning uses various learning format such as project-based learning, case-study learning, small group discussion, verbal presentation, and learning result record which can help learners understand better, stimulate motivation in learning engineering courses, aware of teamwork and accept comments from instructors and colleagues. This result is congruent with the research work of Thaman, Richa, Sukhjinder, et al. [5] about Promoting Active Learning in Respiratory PhysiologyPositive Student Perception and Improved Outcomes. The research result found that active learning helped learners understand learning content better, leading to higher attention, better interaction with friends and good clinical content linkage. Active learning caused higher attention, understanding, and interaction, which help learners participate in learning process. Various learning process helps instructors and learners to be more enthusiastic in learning. In summary, e-learning for enhancing active learning of pre-service teachers can be used to develop learners to gain better achievement result and can be used with learners in every level. According to the analysis of learners' attitude on positive e-learning for enhancing active learning, we found that overall attitude is at the highest level because learners realize that learning through electronics media is beneficial for themselves and leads to behavioral intention in learning through electronics media because attitude is derived from a person evaluate stimulant and transform into internal feeling, causing motivation in expressing of individual behavioral attitude from learning experiences and social stimulants.

This research result is congruent with research result of Piya Boocha Ungsinun Intarakamhang and Chintana Tansuwannond [10] that studied about The Causal Relationship Model of Psychosocial Factors Affecting e-learning Behaviour of Undergraduate Student. The awareness of behavioral control attitude on e-learning and social sponsorship have direct influences on behavioral intention and found that learners were happy when they learned through e-learning in the highest level. The motivation for achievement has direct influences on attitude of e-learning and has indirect influences on behavioral intention trough e-learning. This indicates that learners have 
more motivation for achievement, they will make learners have better attitude toward e-learning.

\section{SugGestions}

Should research and develop e-learning for enhancing active learning by adding various learning strategies, leading to efficient learning. And should research and develop learning format that help increase efficient e-learning for enhancing active learning that is corresponding to information technological advancement and telecommunications.

\section{CONFLICT OF INTEREST}

The author declares no conflict of interest.

\section{AUTHOR CONTRIBUTIONS}

The paper is written by the author independently.

\section{REFERENCES}

[1] Office of the Education Council. Education Plan 2017-2036. [Online]. Available: http://www.onec.go.th/1540

[2] G. Marta, "LMS portal moodle in technical professional language teaching," TEM Journal, vol. 7, no. 1, pp. 188-192, 2018.

[3] M. Chet and J. B. Thomas, Promoting Active Learning, San Francisco, Jossey-Bass, 1993.

[4] M. Marcia et al., "Active learning in first-year engineering courses at Universidad Católica de la Santísima Concepción, Chile,” Australasian Journal of Engineering Education, vol. 19, no. 1, pp. 27-38, 2013.

[5] T. R. Sukhjinder et al., "Promoting active learning in respiratory physiology-positive student perception and improved outcomes,"
National Journal of Physiology, Pharmacy \& Pharmacology, vol. 3, no. 1, pp. 27- 34, 2013.

[6] Silverman et al. (2002). Standards for Online Learning. [Online]. Available: http://iris.nyit.edu/tbls/thefourlevelsofonlinecoursesfinal.pdf

[7] M. E. Shaw and J. N. Wright, Scale for the Measurement of Attitudes, New York, McGraw-Hill, 1967.

[8] Brown et al., Instruction Technology, Media and Method, New York: McGraw-Hill, 1983.

[9] J. Autthaporn and P. Koraneekid, "Development of an active online instructional model to enhance learning behaviors of undergraduate students," Online Journal of Education, vol. 9, no. 4, pp. 122-136, 2014.

[10] P. B. U. Intarakamhang and C. Tansuwannond, "The causal relationship model of psychosocial factors affecting e-learning behavior of undergraduate student," Journal of Behavioral Science, vol. 24, no. 1, pp. 83-101, 2018.

Copyright $(\odot 2019$ by the authors. This is an open access article distributed under the Creative Commons Attribution License which permits unrestricted use, distribution, and reproduction in any medium, provided the original work is properly cited (CC BY 4.0).

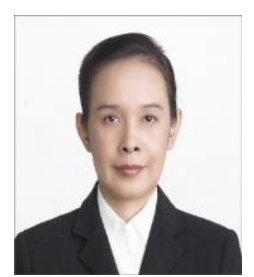

Intira Robroo was born Nakhon Sawan TH. She received the B.Ed. degree in library science from the Chandrakasem Teacher College, TH, in 1991, the M.A. degree in library and information science from the Srinakharinwirot University, $\mathrm{TH}$, in 2002, the $\mathrm{Ph} . \mathrm{D}$. degree in technical education technology from King Mongkut's University of Technology North Bangkok, TH in 2010. She is currently an assistant professor at the faculty of education Sunandha Rajabhat University. She is a lecturer of educational technology and computer department, a chairman of the instructional design program, graduate school and external assessor for Office of National Education Standards and Quality Assessment, TH. Her research interests cover the pedagogy and educational innovation and technology. 